\title{
Trophic interactions between key predatory fishes and crustaceans: comparison of two Northwest Atlantic systems during a period of ecosystem change
}

\author{
Earl G. Dawe ${ }^{1, *}$, Mariano Koen-Alonso ${ }^{1}$, Denis Chabot ${ }^{2}$, Don Stansbury ${ }^{1}$, \\ Darrell Mullowney ${ }^{1}$
}

${ }^{1}$ Fisheries and Oceans Canada, Northwest Atlantic Fisheries Centre, PO Box 5667, St. John's, Newfoundland A1C 5X1, Canada

${ }^{2}$ Fisheries and Oceans Canada, Maurice Lamontagne Institute, 850 Route de la Mer, Mont-Joli, Québec G5H 3Z4, Canada

\begin{abstract}
This study shows that a sharp ecosystem transition in dominant communities during the early 1990s, from finfish to crustaceans, was common to the 2 northernmost Northwest Atlantic ecosystems, the Newfoundland-Labrador shelf (NL) and the northern Gulf of St. Lawrence (nGSL). Fishery and survey data show that populations of Atlantic cod Gadus morhua, typical of most finfish species, collapsed during the late 1980s to early 1990s in both systems, while Greenland halibut Reinhardtius hippoglossoides populations changed little. Biomass of northern shrimp Pandalus borealis increased following the collapse of cod in both systems, likely due, at least in part, to release of predation pressure. Predation appeared to have relatively little effect on biomass of snow crab Chionoecetes opilio. Shrimp replaced capelin as the principal prey in the diet of NL cod and nGSL Greenland halibut in the mid-1990s. The contribution of shrimp to the predator diets was generally highest when neither capelin nor other suitable prey (fish or squid) were available. We conclude that the NL and nGSL ecosystems are similar in form and function, differing from Canadian Atlantic ecosystems further south. The implications of a change in predominant forage species from capelin to shrimp in these systems are unknown, but could conveivably include changes in the pathway and efficiency of energy flow.
\end{abstract}

KEY WORDS: Canadian Atlantic · Predation · Atlantic cod · Greenland halibut · Northern shrimp · Snow crab

\section{INTRODUCTION}

Many subarctic marine ecosystems have experienced transitions to altered states of structure and functioning, associated with pronounced shifts in oceanographic regimes ('regime shifts'; Choi et al. 2004, Frank et al. 2006, 2007, Mueter et al. 2009, Shackell et al. 2010). Clearest examples of such transitions include Northeast Pacific and Northwest Atlantic ecosystems. In the Northeast Pacific (eastern Bering Sea and Gulf of Alaska), a shift from a cold to a warmer regime in the mid-1970s was associated with a change in predominant communities and commercial fisheries from decapod crustaceans to demersal fishes (Litzow \& Ciannelli 2007, Mueter et al. 2009). In contrast, in the Northwest Atlantic (the Newfoundland-Labrador shelf, NL; Gulf of St. Lawrence, GSL; and eastern Scotian Shelf, ESS) a prolonged cold period during the 1980s and early 1990s was associated with a transition from demersal fish to decapod crustacean communities (Lilly et al. 2000, 2008, Choi et al. 2004, Frank et al. 2006, 2007, Lilly 2008, Bundy et al. 2009, Dwyer et al. 2010). In both oceans, the transitions were initially attributed either 
exclusively or primarily to excessive exploitation leading up to the transition (e.g. Hutchings \& Myers 1994, Armstrong et al. 1998). It is now generally believed, for the Northwest Atlantic, that shifts in ocean climate regime played an important role in those transitions, with fishing pressure representing a strong forcing factor (Lilly 2008, Lilly et al. 2008).

It has been argued that bottom-up control is the primary basic controlling mechanism for species abundance, and that ecosystems become vulnerable to top-down control following perturbation, particularly in the ocean climate regime (Litzow \& Ciannelli 2007). It has also been proposed that cold, low-diversity, high-latitude ecosystems are more susceptible to top-down control following perturbation than are warmer ecosystems at lower latitudes, with higher diversity (Frank et al. 2006, 2007). The underlying rationale is that low diversity in high-latitude functional groups such as demersal fishes limits the community capability to compensate for the removal of dominant species.

In the Northwest Atlantic, the change in community dominance from demersal (predatory) fishes to decapod crustaceans was characterized by the collapse of Atlantic cod Gadus morhua and most other commercially important demersal fish stocks (KoenAlonso et al. 2010); only a few stocks, primarily of arctic species such as Greenland halibut Reinhardtius hippoglossoides, did not collapse. This collapse occurred during a prolonged cold oceanographic period, from about 1982 to 1995 at NL, the longest such cold period within the $50 \mathrm{yr}$ monitoring time series (Colbourne \& Anderson 2003, Colbourne et al. 2009). It is believed that the unfavorably cold conditions adversely affected survival of pre-recruit fish (Colbourne \& Anderson 2003). Abundances declined for the entire fish community, including noncommercial species (M. Koen-Alonso unpubl. data). This collapse was concurrent with (or followed by) increases in abundance of commercially important decapod crustaceans, especially northern shrimp Pandalus borealis and snow crab Chionoecetes opilio. The relative effects of ocean climate variability, exploitation, and changes in predation pressure on this transition remain controversial (Lilly et al. 2000, 2008, Worm \& Myers 2003, Choi et al. 2004, Frank et al. 2005, 2006, 2007, 2011, Chabot et al. 2008, Dawe et al. 2008, Petrie et al. 2009, Boudreau et al. 2011). Populations of Atlantic cod and other demersal fishes have not recovered despite the persistence of warm oceanographic conditions (Colbourne \& Anderson 2003, Colbourne et al. 2009) and a moratorium on fishing in some areas for the past $15 \mathrm{yr}$.
In this study, we investigated the effects of changes in relative abundance of predatory demersal fishes and their crustacean prey in severely perturbed highlatitude Northwest Atlantic ecosystems. We adopted a comparative approach between the northern GSL (nGSL) and NL ecosystems, drawing inferences from trends in abundance based on fishery and survey data, trends in diets of principal predators, and trends in spatial interactions between predators and their prey. Our specific objectives included evaluating the degree of similarity in ecosystem transition between our study systems. We also address the role of predation, relative to other forcing factors, in regulating the abundance of dominant and commercially important crustacean populations (northern shrimp and snow crab) in both systems. We then very generally compare our results from the 2 most northern Northwest Atlantic ecosystems to recent changes in predator-prey dynamics in more southern Canadian ecosystems, the southern GSL (sGSL) and the ESS. Finally, we discuss the possible effects of such relative changes in Northwest Atlantic systems on ecosystem structure and function.

\section{MATERIALS AND METHODS}

\section{Study areas and species}

We selected the nGSL and NL ecosystems for this comparative study, as they represent the northernmost ecosystems in the Northwest Atlantic for which survey abundance and biomass data, as well as predator diet data, are available. We selected Atlantic cod and Greenland halibut as our indicators of predation by demersal fish primarily because diet data are available for both of these predators from both ecosystems. Also, Atlantic cod was historically the most abundant predator, known to prey on both northern shrimp and snow crab (Lilly 1984, 1991), and the collapse of its stocks reflects the collapse of most stocks of predatory demersal fishes (KoenAlonso et al. 2010). Greenland halibut is an important predator on northern shrimp in both ecosystems (Parsons 2005a,b, Savenkoff et al. 2006, Dwyer et al. 2010) and is currently the most abundant demersal predatory fish species in both ecosystems.

For the NL ecosystem, we selected an area from the southern Labrador shelf to the northern Grand Bank (North Atlantic Fisheries Organization, NAFO, Div. 2J3KL, Fig. 1), as it represents an ecologically distinct subunit from the southern Grand Bank (NAFO Div. 3NO, Fig. 1; Koen-Alonso et al. 2010). 


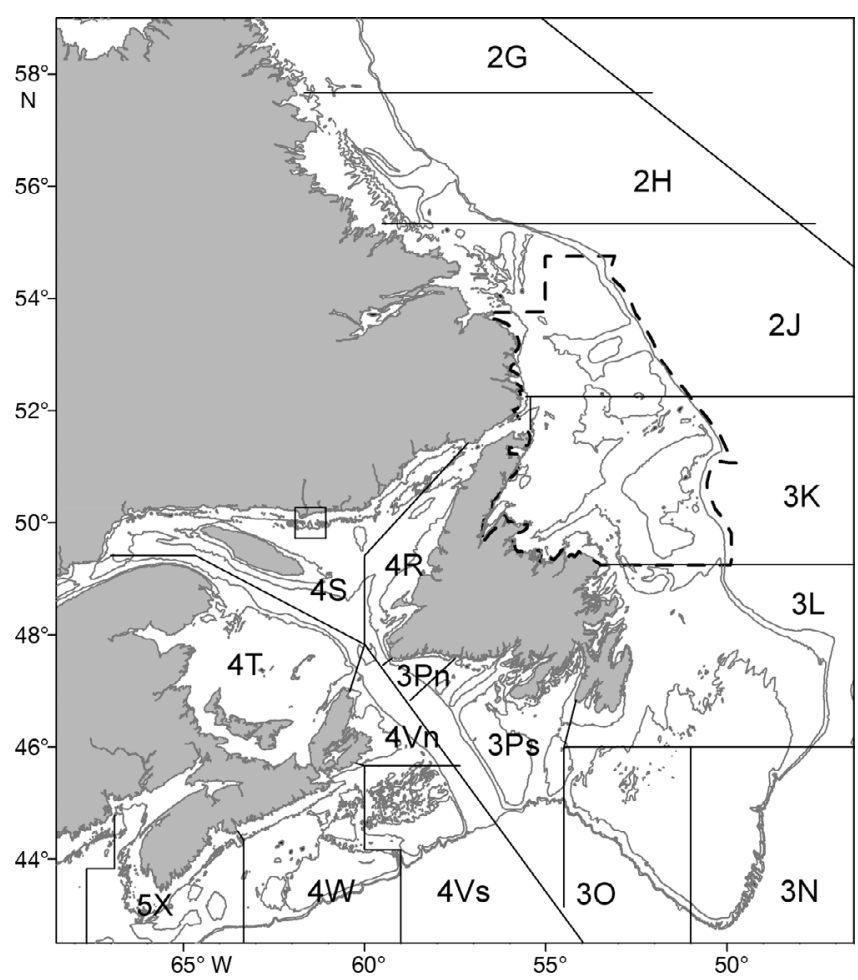

Fig. 1. North Atlantic Fisheries Organization (NAFO) Divisions and dominant bathymetric features on the Newfoundland-Labrador shelf and the Gulf of St. Lawrence, Canada. Shrimp fishing area 6 is bounded by the dashed line. The approximate location of snow crab management area 15 is indicated by the small square

This area also represents the historical distribution of the northern cod stock. Our other study species have broader spatial distributions that include this area. The nGSL ecosystem includes NAFO Div. 3Pn4RS and the deep northwestern portion of Div. 4T (Fig. 1).

\section{Fishery and survey data and indices}

Data on commercial landings $(\mathrm{kg})$ for NL were obtained from the Statistics Division, Policy and Economics Branch, Newfoundland Region of Fisheries and Oceans Canada. Landings for nGSL were available from the Division of Fisheries Science and Aquaculture, Maurice Lamontagne Institute (MontJoli, Québec).

Catch rates, biological data, and stomach data were obtained from bottom trawl surveys in each ecosystem. Survey data for NL were available from fall (September to December) multispecies depthstratified surveys conducted by 2 research vessels from southern Labrador to the tail of the Grand Bank (Div. 2J3KLNO, Fig. 1). This survey series began in
Div. 2J3K in 1978 and extended to the more southern divisions in 1981. The survey trawl was changed in 1995 from the Engel 145 Hi-Lift Otter Trawl to a Campelen 1800 shrimp trawl (McCallum \& Walsh 1996, Walsh \& McCallum 1996). The Engel Hi-Lift Otter Trawl is a large-meshed $(160-180 \mathrm{~mm})$ trawl fitted with a $28.5 \mathrm{~mm}$ codend liner. It has a wingspread of 17 to $22 \mathrm{~m}$ and a vertical opening of 4 to $6 \mathrm{~m}$. It has a steel bobbin and rubber roller footgear and was deployed throughout the diel cycle in standard tows of 30 min duration at a tow speed of 3.5 knots. The Campelen 1800 survey trawl is a smallmeshed $(80,60$, and $44 \mathrm{~mm})$ shrimp trawl that is fitted with a $12.7 \mathrm{~mm}$ mesh codend liner. It has an average wingspread ranging from 15 to $18 \mathrm{~m}$ and an average vertical opening of 4 to $5 \mathrm{~m}$. It has rockhopper footgear featuring $355 \mathrm{~mm}$ diameter rubber disks spaced at $200 \mathrm{~mm}$ intervals along the $19.6 \mathrm{~m}$ footrope. Survey tows, executed throughout the diel cycle at depths of about 50 to $1500 \mathrm{~m}$, were standardized to 15 min duration at a tow speed of 3.0 knots. A conductivity, temperature, and depth (CTD) sensor was mounted on the trawl head rope, and a SCANMAR acoustic net monitoring system was used to monitor trawl performance at each station. Unsuccessful tows were repeated at the same or alternate stations. The annual coverage of survey strata was variable, with inshore strata and strata deeper than $750 \mathrm{~m}$ along the slope edges not surveyed in all years, including the most recent years. Conversion factors between the 2 survey trawls, based on comparative fishing experiments in 1995 and 1996, only exist for a few commercially important fish species, including Atlantic cod and Greenland halibut (Warren 1996, Warren et al. 1997). Catches from the Engel trawl for most species were converted to Campelen equivalents. The Campelen trawl catches more shrimp and crabs than the Engel trawl, such that the survey series for northern shrimp and snow crab begins in 1995. Further details on the treatment of survey data and biological sampling for northern shrimp and snow crab can be found in Orr et al. (2011) and Dawe et al. (2011), respectively.

Data were available for the nGSL from August to early September surveys conducted throughout Div. 3Pn4RS and deep 4T (Fig. 1) during 1990 to 2010. This survey area encompassed the spatial distribution of the Div. 3Pn4RS cod stock in the northern gulf. The survey followed a stratified random sampling plan according to predetermined depth strata. It was conducted from 1990 to 2003 on the CCGS 'Alfred Needler' with a 81'/114' URI (GOV) $44 \mathrm{~mm}$ stretched mesh shrimp bottom trawl equipped with a $19 \mathrm{~mm}$ 
codend liner (Bourdages et al. 2003). In 2004, ship and gear changed and the survey was conducted on the CCGS 'Teleost' equipped with a 4-panel shrimp trawl, the Campelen 1800, as described above and by Bourdages et al. (2004). The duration of a standard tow conducted at a speed of 3 knots was 24 min on the 'Needler' and 15 min on the 'Teleost.' The corrections made for differences in catchability between the 'Needler' and the 'Teleost' are described by Bourdages et al. (2007). The 4 species discussed here had higher catchability on the 'Teleost,' and the 'Needler' data (from the URI trawl) were converted into 'Teleost' (with Campelen trawl) equivalents.

Survey methodology in both study areas included determination of total catch number and weight by species. Biological sampling of all commercially important species includes determination of individual size, sex, and maturity. Size was represented by total length $(\mathrm{cm})$ for the fishes and by carapace width $(\mathrm{mm})$ and length $(\mathrm{mm})$ for snow crab and northern shrimp, respectively. For all 4 study species, except nGSL snow crab, biomass indices were generated by areal expansion methods, for various population components, including the exploitable biomass. More detailed information is available elsewhere regarding collection and treatment of survey data for NL cod (Brattey et al. 2010), nGSL cod (Fréchet et al. 2009), Greenland halibut (Bourdages et al. 2010, Healey 2011), northern shrimp (Savard \& Bourdages 2010, Orr et al. 2011), and NL snow crab (Dawe et al. 2011).

In some cases where survey data series were lacking (nGSL snow crab) or limited (NL northern shrimp and snow crab), we used longer time series of fishery catch per unit effort (CPUE), as an alternate exploitable biomass index. Snow crab CPUE (kg [trap haul $^{-1}$ ) was estimated from commercial landings $(\mathrm{kg})$ and fishing effort (number of trap hauls) obtained from vessel logbooks. These data, from NL, were compiled by the Statistics Division, Policy and Economics Branch, Newfoundland Region of Fisheries and Oceans Canada. The longest time series of CPUE data (from NAFO Div. 3L, Fig. 1) was selected to illustrate trends in snow crab biomass at NL. This CPUE series is unstandardized in that it does not account for variation in fishing practices (e.g. soak time and mesh size). A standardized CPUE series was obtained for Management Area 15 to illustrate trends in nGSL snow crab (Fig. 1). Northern shrimp standardized CPUE $\left(\mathrm{kg} \mathrm{h}^{-1}\right)$ from Shrimp Fishing Area 6 at NL (Fig. 1) was selected for our purpose, as that area includes Div. 3K and southern Div. 2J, representing the central portion of our NL study area.

\section{Stomach collection, examination, and diet analysis}

Length-stratified sampling of stomachs from both cod and Greenland halibut was conducted during the NL fall bottom trawl surveys. In early years, stomachs were fixed and preserved using formaldehyde in seawater solution, but after 1995, they were frozen onboard; stomach contents of both predators were later examined in detail in the laboratory. Data from detailed stomach analysis for cod were available for 1978 to 1996 and 2008 to 2009. Further details on methods of collecting and examining Atlantic cod stomachs during 1978 to 1996 can be found in Lilly (1991) and Lilly et al. (2000). Data from detailed examination of Greenland halibut stomachs were available for the period 1978 to 2003, but no data were collected for 5 years within that period (1980, 1989, 1990, 1994, and 2002). Further details on methods of collecting and examining Greenland halibut stomachs can be found in Dwyer et al. (2010).

In years when stomachs were not taken for detailed examination, routine onboard sampling included quickly opening stomachs and identifying the dominant prey type (qualitative stomach contents). To fill in the large gap in the cod detailed diet series (1997 to 2008) and the missing years in the Greenland halibut series, the diet was reconstructed by combining the frequency of occurrence of prey types as dominant prey, by weight, in a stomach (based on qualitative stomach contents), and its mean weight when they were a dominant prey type in a stomach (based on detailed stomach analysis). The basic rationale for this approach is described in ICES (2008). The more continuous time series of modeled diets will be used in describing trends for NL predators. Although there are some differences in relative contribution by prey categories between stomach sampling methods, the major trends in diet composition were similar between methods (M. Koen-Alonso unpubl. data).

In the nGSL, stomachs of both predator species were excised and frozen at sea. Atlantic cod stomachs were collected according to a length-stratified design during the annual August survey. Up to 3 stomachs were collected from each $10 \mathrm{~cm}$ length class in each set in 1993 and 1994. From 1995 until 2005, 3 stomachs were collected from each $3 \mathrm{~cm}$ length class per set. This was changed to 2 stomachs per $3 \mathrm{~cm}$ length class in 2006 to 2009. It is assumed, for both areas, that predator diets at the time of the surveys are broadly representative of diets throughout the year. 
The stomach sampling protocol for nGSL Greenland halibut was the same as for cod in 1993 to 1996. In 1997, up to 3 Greenland halibut stomachs were collected for each $3 \mathrm{~cm}$ length class for each set in Div. 3Pn4R, but only for odd set numbers in Div. 4S. In 1998, stomachs were collected from 1 male and 1 female for each $1 \mathrm{~cm}$ length class $(2 \mathrm{~cm}$ length class in 1999) for each odd-numbered set for the entire survey area. No Greenland halibut stomachs were collected in 2000. In 2001, stomachs were collected from 1 male and 1 female for each $3 \mathrm{~cm}$ length class for each odd-numbered set, except in strata 801 and 812 to 814 in Esquiman Channel, where all sets were sampled. The same protocol was followed in 2002 to 2009, but all sets from the estuary (strata 411 to 414 ) were sampled. Starting in 2008, 2 males and 2 females were sampled per $3 \mathrm{~cm}$ length class above $49.1 \mathrm{~cm}$, if available, to increase sample size for large fish.

Detailed examination of stomachs in both ecosystems involved determination of the total mass of the contents of each stomach. Prey composition was determined to the lowest taxonomic level possible, and weight of each prey type was determined. Analysis of the diet composition involved determining the percentage by mass that each prey type contributed to the total diet. The raw length-stratified data were summarized to facilitate comparison of annual trends in prey composition between the detailed nGSL series (1993 to 2009) and the reconstructed NL series (1978 to 2009). In order to facilitate comparisons and identify main patterns among species and ecosystems, prey composition was summarized into 5 primary categories; capelin Mallotus villosus, other fishes, shrimps, crabs, and other invertebrates.

\section{Spatial interactions}

Spatial interactions between predators and their crustacean prey were analyzed by first identifying, based on the literature and our own data, the size groups of each fish predator and crustacean prey that are most important in each pairwise predator-prey interaction (Table 1). No information was available regarding sizes of Greenland halibut that may be capable of preying upon crabs, because crabs are only very rarely found in Greenland halibut stomachs. Therefore, the same size groups identified for Atlantic cod-snow crab predation were used to explore spatial interactions of snow crab with potential Greenland halibut predators. Survey catches (num-
Table 1. Gadus morhua and Reinhardtius hippoglossoides. Size relationships in the predation by Atlantic cod and Greenland (G.) halibut on crabs and shrimp

\begin{tabular}{|lcll|}
\hline Predator & Size $(\mathrm{cm})$ & \multicolumn{1}{c}{ Prey } & \multicolumn{1}{c|}{ Source } \\
\hline Cod & $(50-80)$ & Crab <50 mm & $\begin{array}{l}\text { Lilly }(1984,1991), \\
\text { Chabot et al. (2008) }\end{array}$ \\
& $(20-65)$ & Shrimp all & $\begin{array}{l}\text { Lilly (1984, 1991) } \\
\text { G. halibut }\end{array}$ \\
& $(50-80)$ & Crab <50 mm & Dwyer et al. (2010) \\
& $(20-50)$ & Shrimp all & Dwyer et al. (2010) \\
\hline
\end{tabular}

bers) of each predator and prey group at each set location were used to calculate the global index of co-location (GIC, Bez \& Rivoirard 2000, Wieland et al. 2007) for each predator-prey pair. This method estimates the center of gravity (CG) and inertia (extent of horizontal distribution in the form of an ellipse around the CG) for each population to determine the overlap between 2 populations. The GIC can range from 0 , reflecting no overlap between populations, to 1 , indicating fully sympatric populations.

\section{RESULTS}

\section{Trends in fisheries}

Trends in commercial landings (Fig. 2) imply that the timing of the final collapse of Atlantic cod stocks was similar between NL and nGSL. Landings declined precipitously from $269000 \mathrm{t}$ in 1988 at NL and $106000 \mathrm{t}$ in 1983 at nGSL to 40956 and $28000 \mathrm{t}$, respectively, in 1992. A moratorium on commercial fishing was imposed in NL in 1992 and in the nGSL in 1994. Since 1995, cod landings have remained below $9000 \mathrm{t}$ at NL and $7000 \mathrm{t}$ at nGSL. While there has been some inshore commercial and recreational cod fishing at NL since the moratorium was imposed, no directed offshore commercial cod fishery has remained at NL. However, the nGSL commercial cod fishery was re-opened during 1997 to 2002 and 2004 to 2010 .

While the timing of this cod fishery collapse was comparable between areas, its magnitude was much greater at NL than at nGSL. The NL fishery collapsed (in 2 phases) from a historical level of about half a million tons during the 1960s (Fig. 2). In contrast, the nGSL fishery collapsed from a historically high level of about $100000 \mathrm{t}$.

While the collapse in the cod fishery typifies similar collapses in most other groundfish stocks, Greenland halibut represents a notable exception in both areas 


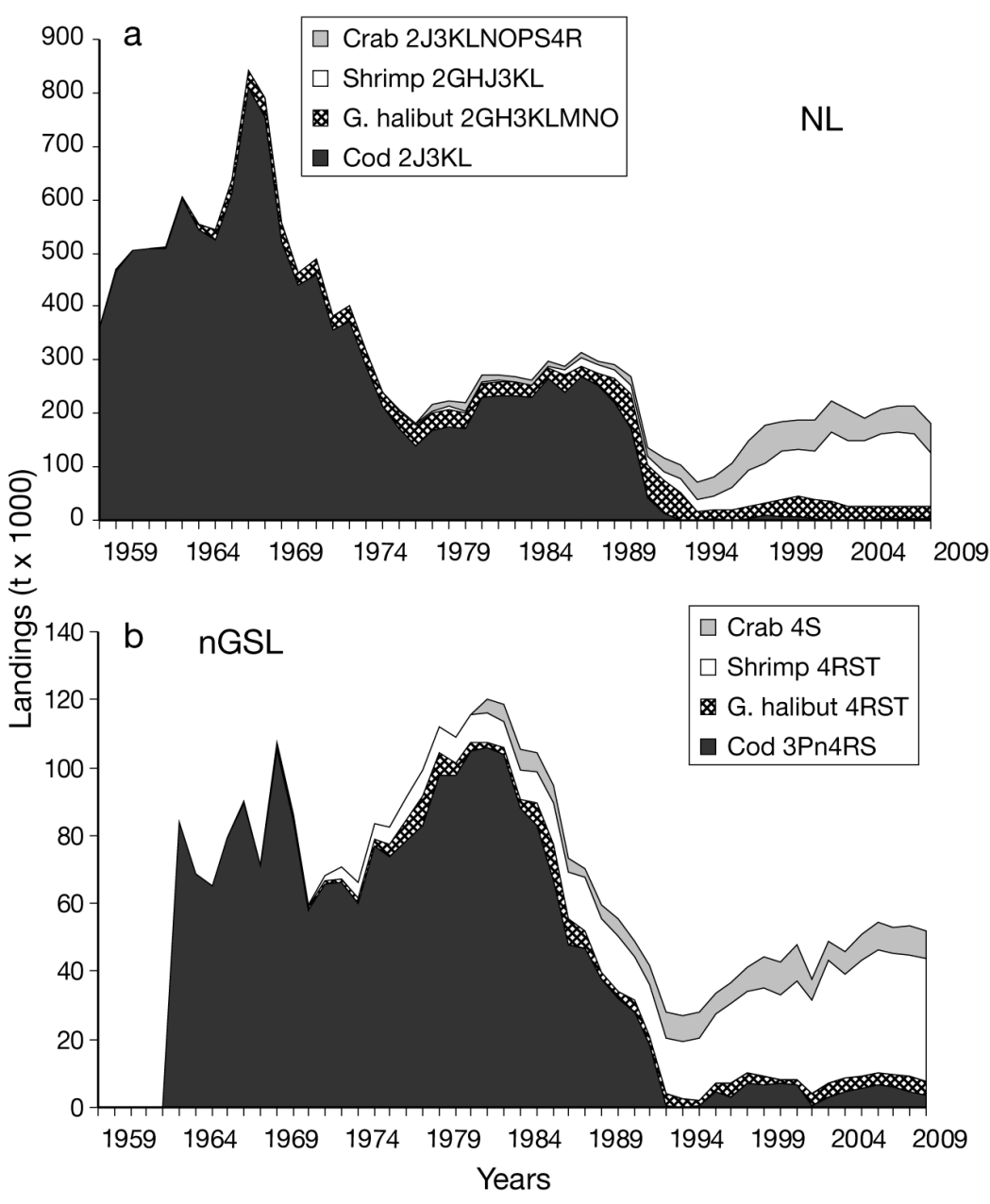

Fig. 2. Annual trends in landings by stock area (stacked in graphs) of snow crab, northern shrimp, Greenland G. halibut, and Atlantic cod (a) on the Newfoundland-Labrador shelf (NL) and (b) in the northern Gulf of St. Lawrence (nGSL)

(Fig. 2). Landings at NL increased from very low levels $(<5000 \mathrm{t})$ in the early 1960s, varying at a higher level of about 20000 to 70000 t since 1990. At nGSL, Greenland halibut landings have varied between 1000 and $4000 \mathrm{t}$ in most years since the late 1970s.

Northern shrimp landings (Fig. 2) at NL increased from less than $5000 \mathrm{t}$ prior to the mid-1980s to peak at 138000 t in 2007, before decreasing in 2009. Northern shrimp landings at nGSL increased from less than $10000 \mathrm{t}$ sprior to the mid-1980s to about $40000 \mathrm{t}$ in recent years.

Snow crab landings (Fig. 2) at NL increased from $<15000$ t during the 1980s to peak at $69000 \mathrm{t}$ in 1999. They have since varied between 44000 and $59000 \mathrm{t}$. Snow crab landings at nGSL varied between 3000 and 6000 t during 1983 to 1993 and between 6000 and 10000 t during 1994 to 2010 (Fig. 2).

\section{Trends in biomass}

Annual changes in biomass are uncertain due to sampling variability, particularly due to annual changes in survey trawl efficiency. However, some general trends are evident and consistent with fishery trends. For example, survey biomass trends for NL show that the northern cod biomass collapsed during the early 1990s from a level of about 1.0 to $1.5 \mathrm{Mt}$ in the $1980 \mathrm{~s}$ to only about $7000 \mathrm{t}$ in 1993. Meanwhile, Greenland halibut biomass has varied without any clear trend since 1978. Northern shrimp and snow crab biomass indices are available only for the period since the northern cod collapse (Fig. 3). Shrimp biomass increased from 1999 to 2006, as reflected by more than doubling of annual biomass indices despite increasing fishery removals (Fig. 2), but then apparently decreased to 2009. Snow crab biomass was highest during 1996 to 1998 and has since varied at a lower level (Fig. 3).

The relatively short survey series for groundfish from nGSL (Fig. 3) does not capture the final collapse of the Div. 3Pn4RS cod stock that is reflected in the landings trend (Fig. 1). Cod biomass estimates generally remained below 20000 t during 1978 to 2002 but were slightly higher during more recent years (Fig. 3). Greenland halibut biomass estimates have fluctuated greatly around an overall level of about 80000 to $100000 \mathrm{t}$. Northern shrimp biomass showed a similar general trend to that at NL, increasing by about a factor of 4 from the early 1990s to 2004/2005, despite increasing fishery removals (Fig. 2), but then apparently decreased to 2010.

Because of the unavailability of a reliable nGSL survey series for snow crab biomass and the short time series of survey biomass for NL crustaceans, longer time series of fishery CPUE, for both snow crab (NL and nGSL) and northern shrimp (NL), were examined in relation to predator biomass trends (Fig. 4). Northern shrimp CPUE at NL was highly variable during the final years of the cod collapse (1989 to 1994), but then increased by about $60 \%$ to 2008. NL shrimp CPUE decreased in 2009 (Fig. 4), as did shrimp survey biomass (Fig. 3). Snow crab CPUE trends displayed fairly regular oscillations over time in both systems (Fig. 4). While these 2 CPUE series were of differing lengths, it is clear that these oscillations were maintained at NL 

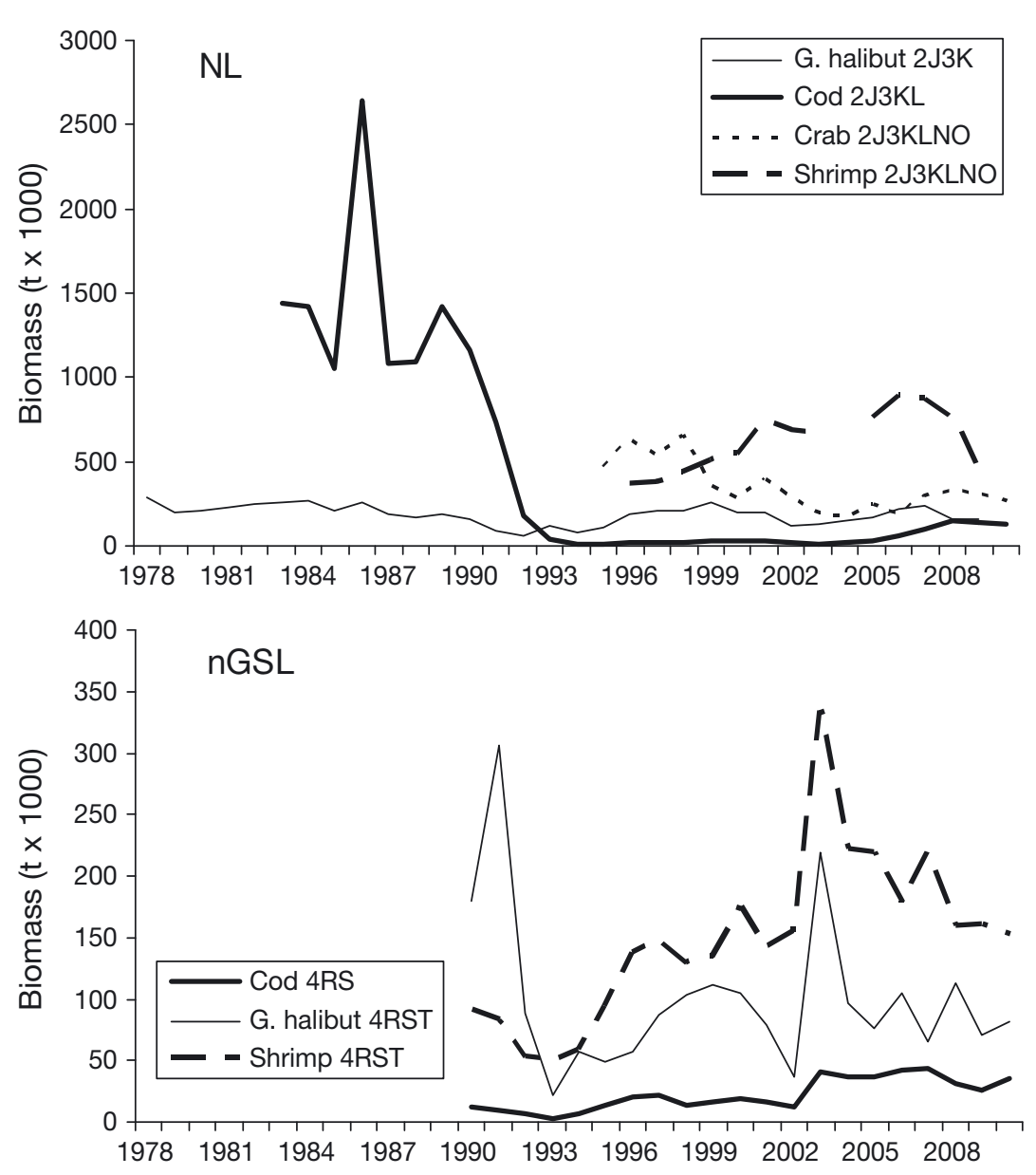

Fig. 3. Annual trends in survey biomass indices of snow crab (Newfoundland-Labrador shelf, NL, only, scaled up by an order of magnitude), northern shrimp, Greenland G. halibut, and Atlantic cod on (a) the NL and (b) the northern Gulf of St. Lawrence (nGSL)

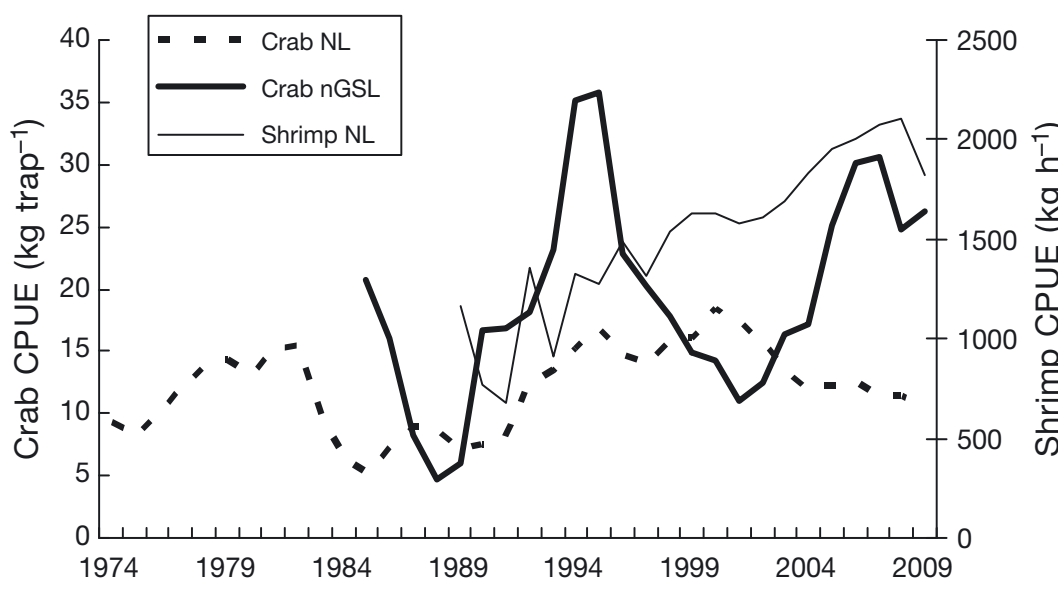

Fig. 4. Chionoecetes opilio and Pandalus borealis. Annual trends in catch per unit effort (CPUE) of snow crab from NAFO Div. 3L and northern shrimp from shrimp fishing area 6 on the Newfoundland-Labrador shelf (NL) and of snow crab from management area 15 in the northern Gulf of St. Lawrence (nGSL) throughout the period of the final cod collapse. The trends showed a peak in CPUE at NL in 1982, prior to the final collapse of cod, that was generally of comparable magnitude to post-collapse peaks. The nGSL snow crab CPUE declined sharply during 1985 to 1988 and then continued to oscillate regularly while the biomass of cod remained at relatively low levels and that of Greenland halibut varied with no clear trend.

\section{Predator-prey spatial interactions}

The spatial distribution of each sizespecific predator and prey pair is illustrated for 2009, as an example (Fig. 5). The location of the CG for each predator and prey group (Fig. 6) generally reflects the more detailed survey distributions. For example, the CGs for nGSL cod reflect a distribution that is concentrated close to the west coast of Newfoundland, well east of the CGs of their shrimp prey, mostly in the western portion of the northern gulf, as seen in the detailed 2009 distributions (Fig. 5). It is uncertain to what extent annual variation in the location of the CG reflects shifts in the geographic distribution of each size-specific predator and prey species, independent of changes in horizontal dispersion (Fig. 6), versus random sampling variability. For example, the annual CGs for shrimp in both areas and for both size groups of Greenland halibut in nGSL are tightly clustered, reflecting virtually no annual shifts in the distributions. In contrast, large predators of both species show highly variable locations of their CGs at NL (Fig. 6), reflecting low abundance and patchy distributions of populations of large fish that are not well sampled by the surveys. Annual variation in location of CGs in the nGSL was more pronounced for snow crab than for any of the other 3 species, likely reflecting low and annually variable capture efficiency of small crabs by the survey trawl.

Differences in GIC values between NL and nGSL (Fig. 7) must be interpreted with caution. The higher values at NL, 

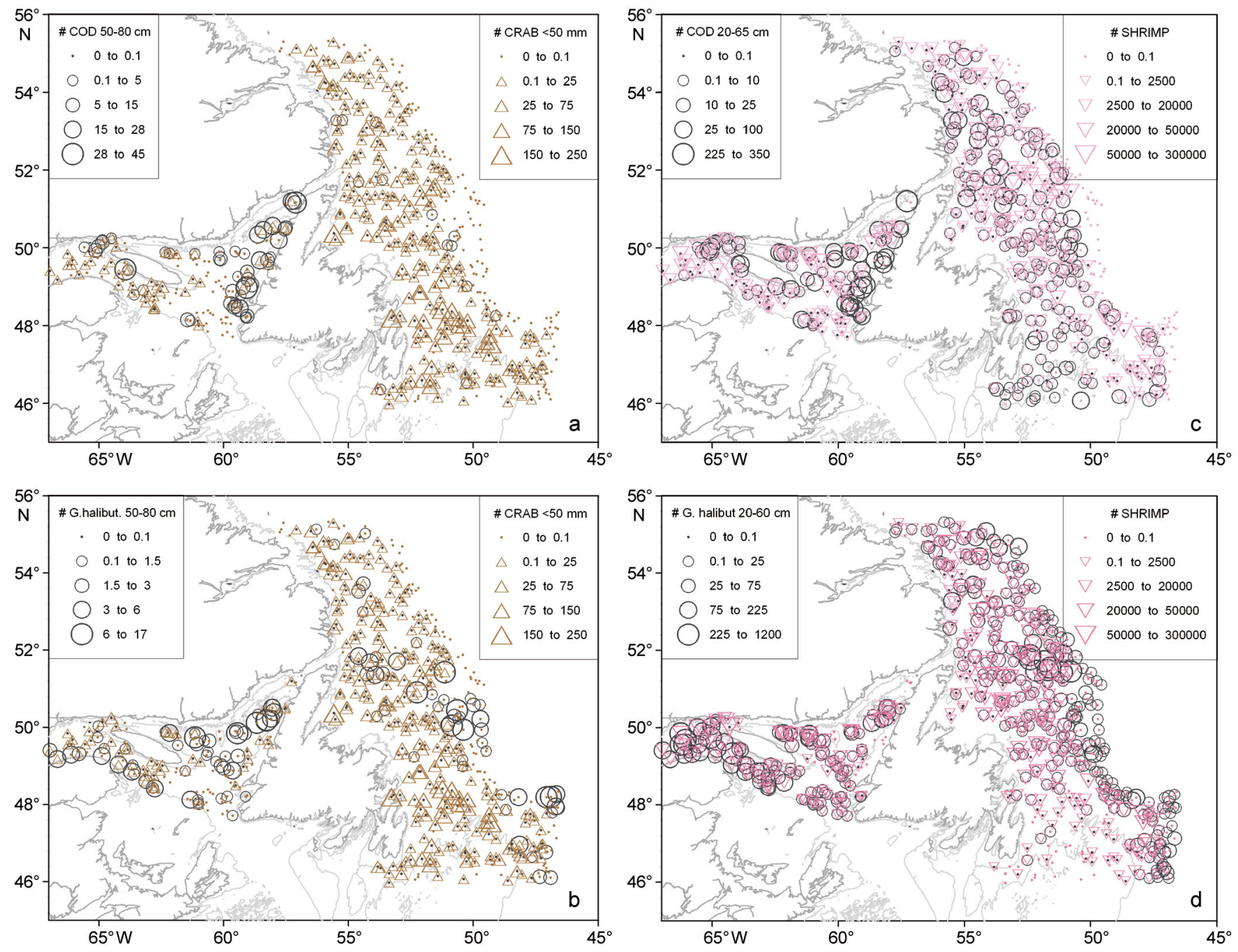

Fig. 5. Distribution of size-specific predator-prey pairs involving $(\mathrm{a}, \mathrm{c})$ Atlantic cod, $(\mathrm{b}, \mathrm{d})$ Greenland $(\mathrm{G}$.) halibut, (a,b) snow crab and $(c, d)$ northern shrimp from surveys on the Newfoundland-Labrador shelf and in the northern Gulf of St. Lawrence. Size of symbols represents catch numbers per survey set within species

especially for shrimp and its predators, may largely be an artifact of broader and more uniformly distributed populations at NL than at nGSL.

Examination of the raw survey catches for our 2009 example year (Fig. 5) shows that northern shrimp overlap more extensively (and evenly) with cod at NL than at nGSL, where cod are most concentrated in the eastern portion of the nGSL, and partially avoid the deep channels, possibly because of hypoxia (Chabot 2004). By contrast, northern shrimp overlap with Greenland halibut more extensively at nGSL than at NL, where the Greenland halibut distribution is concentrated along the deep slope, overlapping with the eastern portion of the shrimp distribution. The lower GIC values for shrimp-Greenland halibut at nGSL than at NL is likely an artifact of the existence of 4 major concentrations of nGSL adult shrimp, with likely very little movement of adults across concentrations (DFO 2012). Notwithstanding these concerns, both predators overlap extensively with at least a portion of the northern shrimp distribution in both areas. Therefore, it is appropriate to make only relative comparisons of GIC between areas.

General comparisons of GIC within areas are appropriate. For example, the GIC for crab and its potential predators at NL was generally lower and more variable than for shrimp and its predators (Fig. 7). At nGSL, the cod-crab GIC was low throughout the short 2004 to 2010 time series, fluctuating between about 0.4 and 0.7 . The closest pairwise interaction at nGSL was between crab and Green- 

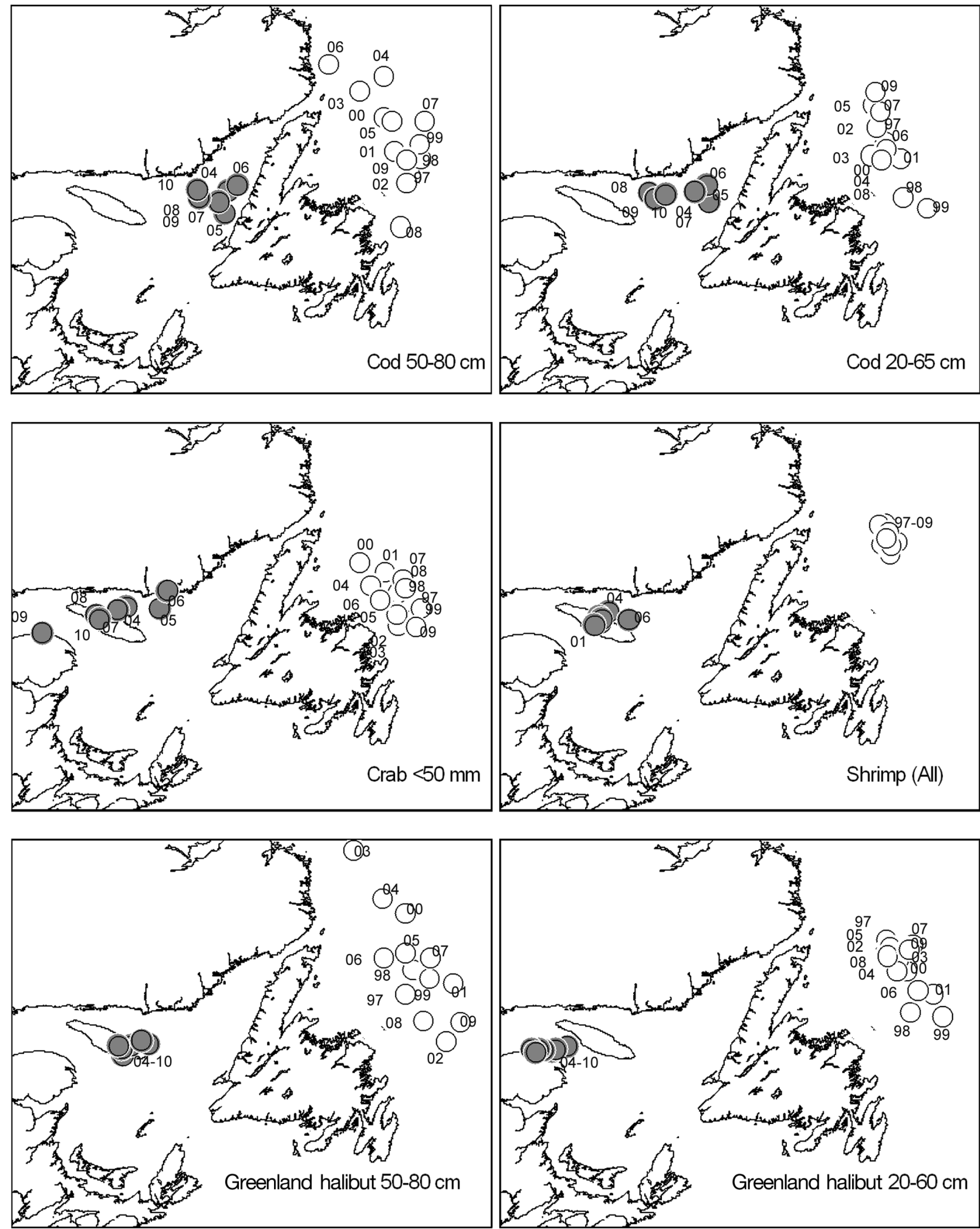

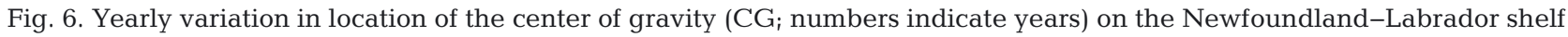
(white circles) and the northern Gulf of St. Lawrence nGSL (grey circles) for size-specific predators and prey relative to predation on snow crab (left column) and on northern shrimp (right column) 
land halibut, with the GIC exceeding 0.9 in all but 1 year (Fig. 7). This close spatial interaction, combined with a lack of crab in Greenland halibut diets, indicates that large Greenland halibut select against available small snow crab as prey.
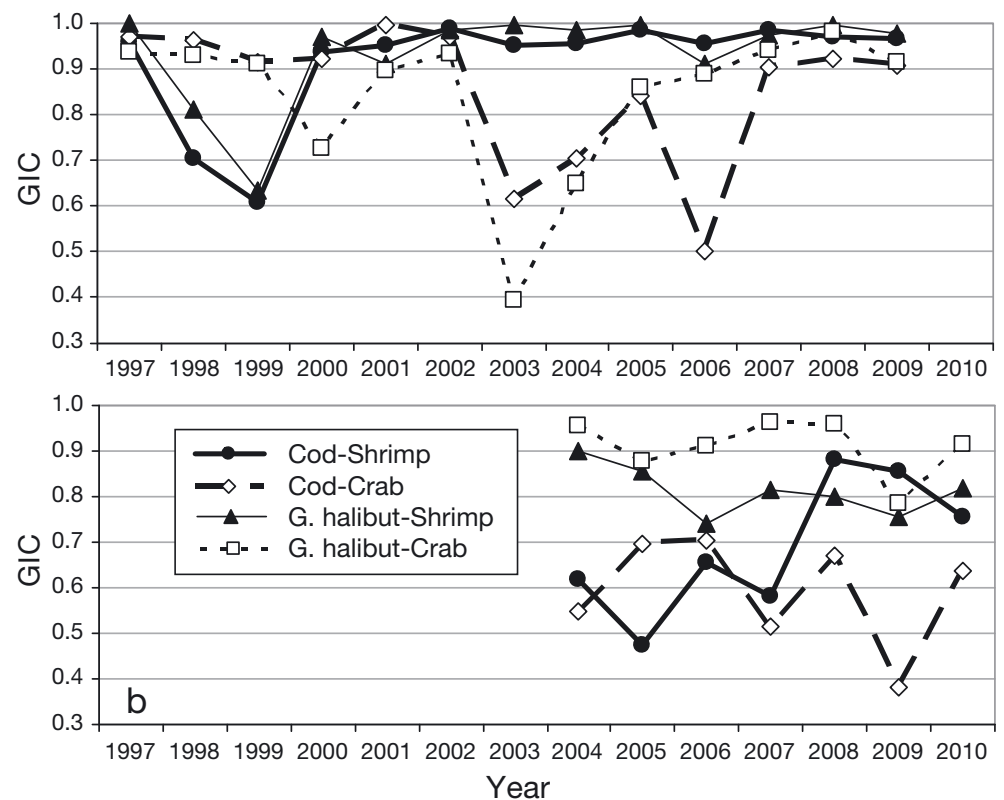

Fig. 7. Annual trends in the global index of co-location (GIC) for each size-specific predator-prey pair on (a) the Newfoundland-Labrador shelf and (b) the northern Gulf of St. Lawrence. Size groups are as described in Table 1

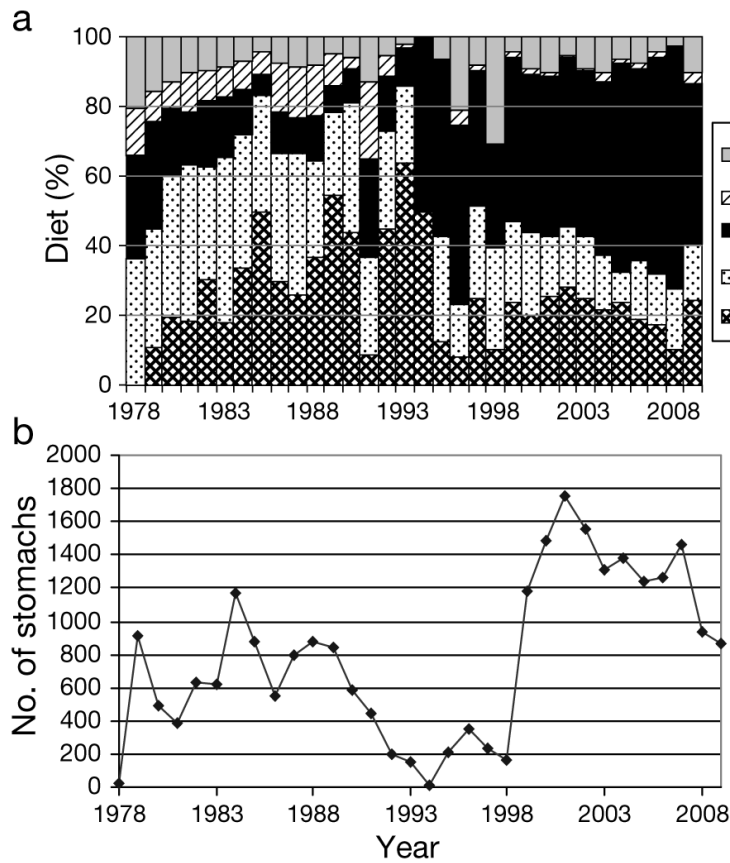

\section{Annual trends in predator diets}

Atlantic cod

Capelin represented the predominant prey type of cod prior to the early 1990s at NL (Fig. 8) and during the first $2 \mathrm{yr}$ of the limited time series at nGSL. The capelin contribution to the cod diet dropped sharply at both NL and nGSL from about $60 \%$ in 1993 to about $10 \%$ in 1995 and has since remained low. The NL cod diet became heavily dependent on shrimp at NL following the decline in capelin prey (Fig. 8), with the shrimp contribution increasing to about $50 \%$ in 1994 and has since remained high. In contrast, at nGSL, other fish prey remained an important component of the cod diet following the drop in capelin prey, varying between about 20 and $55 \%$ (Fig. 8). Meanwhile, the shrimp contribution changed little and remained low, seldom exceeding $20 \%$. The shrimp contribution to the nGSL cod diet increased in 2008 and 2009 as the contribution of other fish decreased (Fig. 8). This coincided with an increase in spatial interaction between shrimp and cod (Fig. 7), due to a westward shift in the cod distribution (Fig. 6), suggesting that cod may actively seek shrimp as prey only when preferred fish prey becomes unavailable.

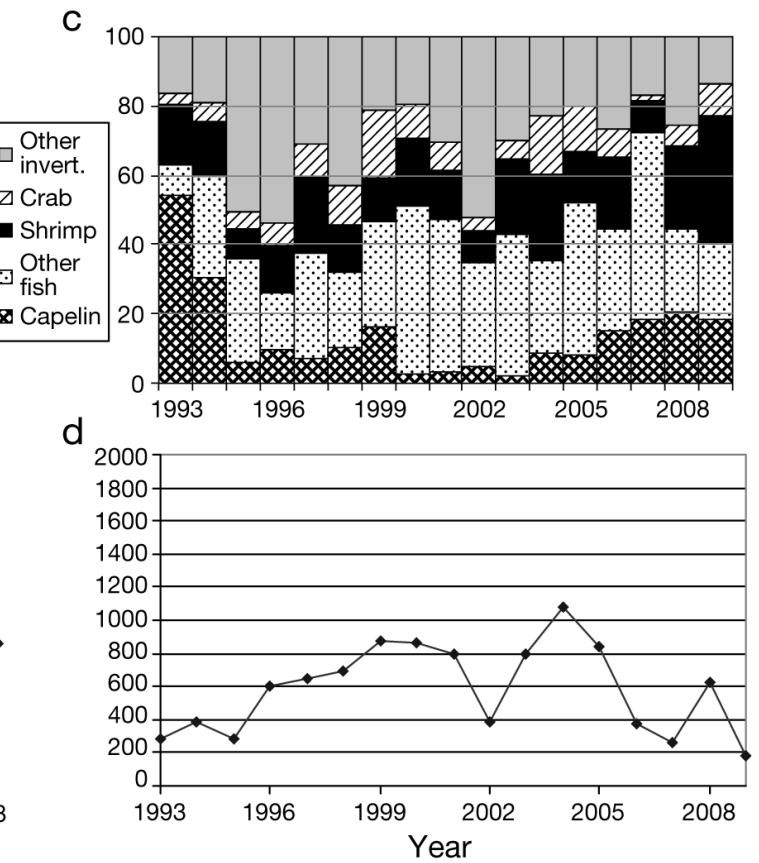

Fig. 8. Gadus morhua. $(\mathrm{a}, \mathrm{c})$ Annual trends in percentage contribution by weight for each of 5 prey categories to the diet of Atlantic cod, with $(b, d)$ number of stomachs examined from $(\mathrm{a}, \mathrm{b})$ the Newfoundland-Labrador shelf (reconstructed diet) and $(c, d)$ the northern Gulf of St. Lawrence (detailed diet) 
a
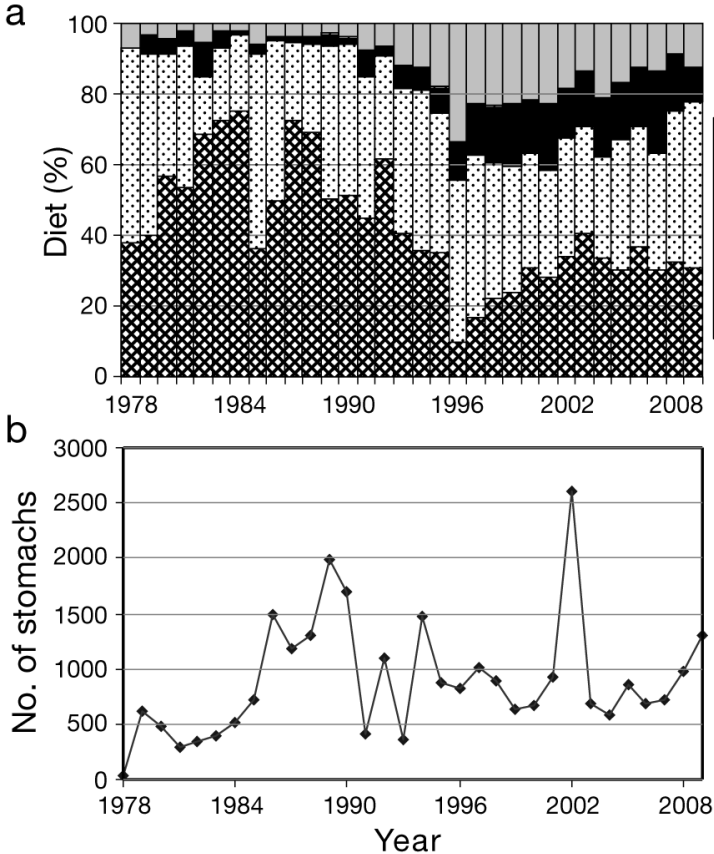

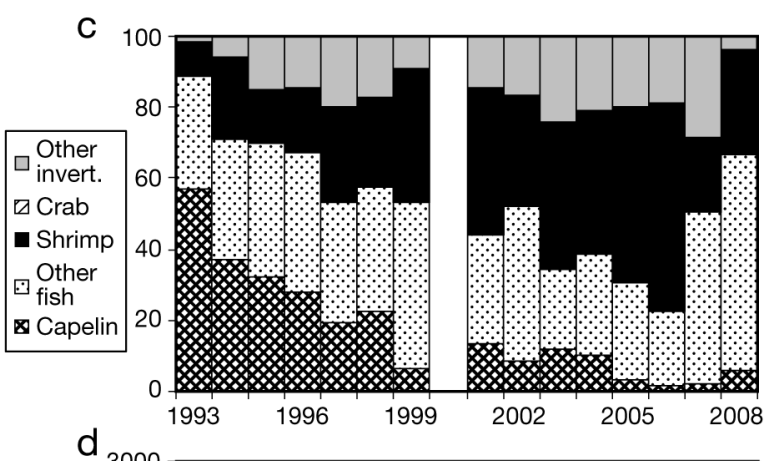

$\mathrm{d}_{3000}$

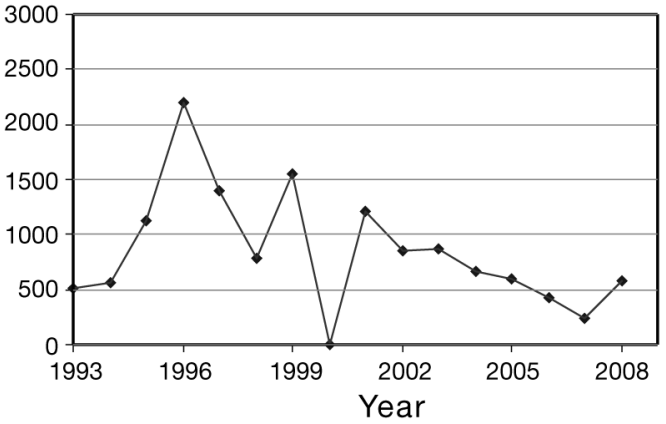

Fig. 9. Reinhardtius hippoglossoides. $(\mathrm{a}, \mathrm{c})$ Annual trends in percentage contribution by weight for each of 5 prey categories to the diet of Greenland halibut, with $(b, d)$ number of stomachs examined from $(a, b)$ the Newfoundland-Labrador shelf (reconstructed diet) and $(\mathrm{c}, \mathrm{d})$ the northern Gulf of St. Lawrence (detailed diet)

The crab contribution to the NL cod diet was generally below $15 \%$ during 1978 to 1990, decreased to $0 \%$ in 1994 , and has since remained virtually absent (Fig. 8). The occurrence of crab in the nGSL cod diet showed no clear trend, ranging between 2 and $20 \%$. This difference between systems in the importance of crab in cod diets is undoubtedly due to greater prevalence of large $(>50 \mathrm{~cm})$ cod at nGSL than at NL (Fig. 5). The contribution by other invertebrates was much more important at nGSL than at NL. The importance of other invertebrates since 1995 varied without trend at NL, but declined at nGSL.

\section{Greenland halibut}

The contribution of capelin to the Greenland halibut diet decreased substantially in the early 1990s in both systems, as it did in the cod diet (Fig. 9). However, the drop in capelin was not as sharp in the Greenland halibut diet as it was in the cod diet. The capelin contribution to the NL Greenland halibut diet dropped sharply in 1996, 1 yr later than its sharp drop in the cod diet (Fig. 8). It increased gradually to about $40 \%$ in 2003 (Fig. 9) and has since varied little. Capelin also declined greatly at nGSL in the 1990s (Fig. 9). Capelin in the nGSL Greenland halibut diet declined from $57 \%$ in 1993 to $7 \%$ in 1999, and has since remained low.
Greenland halibut did not rely as heavily on shrimp as did Atlantic cod at NL following the decline in the capelin contribution around 1995, with other fish remaining an important component of the diet. A reduction in the NL capelin component was compensated for by increases in shrimp and other invertebrates (Fig. 9).

At nGSL (as at NL) other fish remained relatively important in the Greenland halibut diet as capelin declined, ranging between 21 and $61 \%$ and the decline in the capelin component was compensated for by increases in shrimp and other invertebrates. However, the diet became more highly dependent on shrimp than did the diet of NL Greenland halibut (Fig. 9) or of nGSL cod (Fig. 8). At nGSL, shrimp increased steadily from $10 \%$ in 1993 to $59 \%$ in 2006. Snow crab was virtually absent from the Greenland halibut diet in both areas, at $0 \%$ in most years and never achieving $1 \%$ (Fig. 9).

\section{DISCUSSION}

\section{Effects of predation on crustacean populations}

Our results suggest that, at the present time, snow crab populations are not controlled by topdown effects of predation by these 2 fish species. Crabs were virtually absent from the Greenland hali- 
but diet in both areas. Crabs (including snow crab) were never a major component of the Atlantic cod diet in either area, and since the groundfish collapse, they have been virtually absent from the NL cod diet. This is no doubt a result of the very low abundance of large cod at NL in recent years due to the much reduced abundance of older (>age 5), larger (>about $50 \mathrm{~cm}$ ) fish (DFO 2007). It is reasonable to assume that prior to the collapse, during the 1960s and 1970s, predation by large cod populations may have played some role in limiting snow crab abundance. However, snow crab catch rates have maintained regular oscillations in abundance throughout the study period in both systems, including before the final collapse at NL, which is unexplained by the hypothesis of strong top-down control proposed by Boudreau et al. (2011). Other possible controlling mechanisms include density-dependent processes that influence egg production or settlement success (Conan et al. 1996, Sainte-Marie et al. 1996, Sainte-Marie \& Lafrance 2002, Caddy et al. 2005). The most convincing recent evidence, across multiple ecosystems, is that that snow crab populations are controlled by bottomup processes associated with temperature (Orensanz et al. 2004, Dawe et al. 2008, Marcello et al. 2012, this volume)

It seems more likely that northern shrimp, rather than snow crab, populations may be regulated, at least in part, by predation pressure. Although our results were inconclusive because our time series of biomass indices are too short, survey and fishery CPUE trends suggest that northern shrimp biomass in both areas increased following the final groundfish collapse. Lilly et al. (2000) concluded that an initial increase in NL shrimp during the early to mid-1980s was not related to changes in cod, but that a larger increase in shrimp biomass in the 1990s was, at least in part, related to the collapse of cod. They noted that coarse estimates of consumption suggested that consumption of shrimp by cod in the 1980s was lower than fishery removals in the late 1990s, and more than an order of magnitude lower than estimated biomass levels in the late 1990s. They further concluded that consumption of shrimp by cod at NL was very low after 1991 and that this reduction in consumption contributed to the increase in shrimp biomass, which was a function of increased shrimp density as well as area of distribution. They suggested that the fishery has become a more important source of shrimp mortality than predation by cod since the 1990s, when shrimp biomass increased. However, they recognized that total removals by all predators would be higher than that by cod alone.
Besides Atlantic cod and Greenland halibut, redfish Sebastes mentella represents another important predator of northern shrimp (Parsons 2005a,b, Savenkoff et al. 2006). No data are available on redfish diet from our NL study area, but the population trajectory of NL redfish is well-represented by that of northern cod (Koen-Alonso et al. 2010). A study in the nGSL showed that predation has been by far the main source of northern shrimp mortality from the mid1980s to the early 2000s (Savenkoff et al. 2006). Over this time period, Greenland halibut replaced cod and redfish as the main shrimp predator. Total consumption of northern shrimp decreased from the mid1980s to the mid-1990s and was believed to be playing an important role in controlling the shrimp population in that area. Consumption of shrimp increased in the early 2000s, but remained below the mid-1980s level. It is therefore likely that predation in the early 2000s (primarily by Greenland halibut) continued to play an important role in regulating shrimp abundance. This seems especially likely given that in our study, nGSL northern shrimp represented about $40 \%$ of shrimp (all species combined) in the cod diet, but about $80 \%$ of the shrimp in the Greenland halibut diet. This generally agrees with results of studies across multiple ecosystems that trends in shrimp abundance are, at least in part, related to changes in predation pressure (Worm \& Myers 2003).

Regardless of the role of predation in affecting northern shrimp biomass up to the early 2000s, the apparent recent declines in biomass in both areas cannot be attributed primarily to effects of predation. Northern shrimp biomass indices declined by half from 2006 to 2009 at NL and by about one-third from 2004 to 2010 at nGSL. The changes in biomass of cod and Greenland halibut during this recent period are uncertain and marginal in both systems.

There is growing evidence across multiple ecosystems that northern shrimp populations are affected by bottom-up effects associated with temperature and primary productivity (Ouellet et al. 2007, Koeller et al. 2009). Our results further support the idea that there was a major transition in both ecosystems associated with the collapse of the demersal fish community, where northern shrimp abundance appeared to have increased to a higher level as a consequence of release from predation pressure. However, it is unlikely that any population is regulated by a single process, and it is reasonable to assume that ocean climate continues to play a role in affecting shrimp abundance, as the recent drop in survival during early life in many areas of nGSL suggest (DFO 2012). A recent study at West Greenland found that both 
ocean climate variability and predation by Greenland halibut were significant determinants of northern shrimp abundance (Wieland \& Siegstad 2012, this volume).

\section{Comparison across Northwest Atlantic ecosystems}

We found that both predators had ready access to both crustacean prey species throughout the time series. In general, we conclude that our trends in diets reflect overall changes in relative availability of forage species in both systems, since both predators are considered to be opportunistic (Lilly 1991, Hanson \& Chouinard 2002, Dwyer et al. 2010), and in the case of Greenland halibut in NL, positive correlations between diet and prey trajectories have actually been found (Dwyer et al. 2010). The sharp change in prey composition in both systems was due to both a decrease in capelin and increase in shrimp availability. Our data suggest that shrimp consumption is modulated both by shrimp availability and the availability of fish prey. Hence the pronounced shift from capelin to shrimp as principal prey type for NL cod, but not for nGSL cod, could be the result of a greater availability of alternate fish prey in nGSL, where increases in the proportion of Atlantic herring Clupea harengus and pleuronectids were observed in the cod diet. Conversely, NL Greenland halibut increased predation upon other fish (especially grenadiers) and bathypelagic gonatid squid (Dwyer et al. 2010) as capelin availability declined, whereas nGSL Greenland halibut relied on shrimp. This suggests that cod and Greenland halibut are not truly opportunistic, consuming shrimp only when other more suitable prey is not available. This could be due in part to the lower energy content of shrimp (approximately $5 \mathrm{~kJ} \mathrm{~g}^{-1}$, Lawson et al. 1998, D. Chabot unpublished data), compared with capelin (4 to $5 \mathrm{~kJ} \mathrm{~g}^{-1}$ in spring and early summer, 8 to $10 \mathrm{~kJ} \mathrm{~g}^{-1}$ in autumn and winter, Montevecchi \& Piatt 1984, Perez 1994, Lawson et al. 1998, Anthony et al. 2000). This difference in energy density is likely amplified by the fact that gastric evacuation rates can be slower for prey with a carapace that resists digestion (Jobling 1987, dos Santos \& Jobling 1992, Bromley 1994, Andersen 2001, Couturier 2003).

Although there may be some concerns with relying upon reconstructed diets for the NL predators, when detailed stomachs and reconstructed diets based on similar principles to the ones used here have been compared, the differences between methods have been minor for the most part; both approaches pro- vide similar overall pictures of the diet and its major changes over time (Dwyer et al. 2010). Particularly convincing for NL cod is that the detailed stomach analysis data, available for 1978 to 1996, clearly showed the sharp transition during 1994 to 1996 from capelin to shrimp as principal prey type that was also evident in the qualitative data. These datasets also agreed that shrimp remained the principal prey type in the 2 most recent years. Nonetheless, care must be taken when analyzing these types of results to avoid over-interpreting minor variations in diet composition that a coarse-grain approach like this should not be expected to reflect with high accuracy.

Overall, the major trends we described in predator diets (shift from capelin to shrimp prey since 1995) would be expected to reflect a transition common to both ecosystems. The increase in shrimp in both systems is supported by recent trends in survey and fishery biomass indices. The decrease in capelin abundance at NL is supported by results of hydroacoustic surveys (DFO 2010, 2011a) and mass balance modeling (Bundy et al. 2009).

Support for the decline in nGSL capelin is unavailable, due to scanty and conflicting diet-independent information. Bundy et al. (2009) concluded that there has been little change in capelin abundance at nGSL based on mass balance modeling. By contrast, bottom trawl survey data indicate an increase in capelin dispersion and catch rate since 1990 in the nGSL as well as in the sGSL (DFO 2011b). It has been cautioned, however, that these increases may be due to an increase in the depth of capelin distribution, as occurred at NL during the early 1990s (DFO 2010), and consequent increased availability to the survey bottom trawl (McQuinn 2009, Swain \& Mohn 2012). Also, capelin has not featured prominently in the diet of sGSL cod, where the principal prey shifted from euphausiids during 1959 to 1980 to herring Clupea harengus during 1987 to 2000 (Hanson \& Chouinard 2002). We conclude, based on the great similarity that we found in annual trends in capelin prevalence within our predator diets between systems, that capelin abundance decreased in both systems in the mid-1990s and has since remained low. This is further supported by great similarities between these systems in trends in capelin size and other biological and behavioral characteristics (DFO 2011b).

Trends in our study areas support the conclusion of Bundy et al. (2009) that the most northern NL and nGSL ecosystems are similar in form and function, whereas the shallow sGSL system has closer affinity to the most southern ESS ecosystem. Whereas planktivorous forage fishes remain in low abundance in 
the northern systems, they have recently increased in both the sGSL (Hanson \& Chouinard 2002, Bundy et al. 2009) and on the ESS (Frank et al. 2006, Bundy et al. 2009). Bundy et al. (2009) concluded that both the NL and nGSL ecosystems have experienced similar recent changes, with common decreases in many ecosystem parameters including total production, biomass, consumption, and total system throughput.

Current theory holds that depletion of apex predators in subarctic ecosystems has resulted in trophic cascades throughout the ecosystem (Frank et al. 2005), the most immediate effect being an increase in the primary forage species, as appeared to occur on the ESS (Frank et al. 2006). However, in the most northern Northwest Atlantic ecosystems (NL and nGSL), it is clear (especially for NL) that depletion of predators did not result in an increased abundance of the primary forage species, but rather that capelin declined as part of a collapse of the entire finfish community. In these most northern ecosystems, it could be argued that the increase in northern shrimp abundance represented such a cascading effect. However, even shrimp abundance is not simply the result of top-down effects only. Recent declines in shrimp stocks, without any noticeable change in predator abundance, suggest that changes in ocean climate conditions are also affecting shrimp productivity. In any case, these declines do not appear to be linked with strong rebuilding of fish stocks, casting doubts about the trophic cascade hypothesis for these northern ecosystems.

The ultimate effect of the replacement of a historical primary forage fish (capelin) in the ecosystem by crustaceans (shrimp) remains unclear, but unavailability of suitable prey (capelin) has been proposed as one of many factors that may be contributing to high natural mortality and failure of NL cod to recover (Rose \& O'Driscoll 2002, Lilly 2008, DFO 2009, 2011a). The switch from a pelagic planktivorous fish to an omnivorous crustacean as primary prey type may imply a change in the pelagic-demersal coupling within the ecosystem. Conceivably, an increased portion of the ecosystem energy flow might go directly from surface to the bottom, to benefit the benthic community, rather than be channeled through the pelagic domain into traditionally dominant groundfish species.

Acknowledgements. We thank our colleagues who provided data and advice from both the nGSL (P. Schwab, B. Bernier, H. Bourdages, D. Bernier, L. Savard, B. Sainte-Marie, J. Lambert) and from NL (E. Murphy, B. Healey, D. Orr, K. Dwyer, P. Pepin, F. Mowbray, A. Buren, D. Holloway, B. Vaters, N. Wells). Collection of predator diet data by M.K.A. in the NL region was supported by the Fisheries and Oceans (DFO) Ecosystem Research Initiative (ERI) in the
Newfoundland and Labrador Region, the NEREUS program. This study was conducted as part of the internationallycollaborative research program ESSAS (Ecosystem Studies of Sub-arctic Seas); our thanks go to G. Hunt and K. Drinkwater, ESSAS co-chairs, and F. Mueter, co-chair of the ESSAS working group on Climate Effects at Upper Trophic Levels, for organizational support related to this study.

\section{LITERATURE CITED}

Andersen NG (2001) A gastric evacuation model for three predatory gadoids and implications of using pooled field data of stomach contents to estimate food rations. J Fish Biol 59:1198-1217

Anthony JA, Roby DD, Turco KR (2000) Lipid content and energy density of forage fishes from the northern Gulf of Alaska. J Exp Mar Biol Ecol 248:53-78

Armstrong J, Armstrong D, Hilborn R (1998) Crustacean resources are vulnerable to serial depletion-the multifaceted decline of crab and shrimp fisheries in the Greater Gulf of Alaska. Rev Fish Biol Fish 8:117-176

Bez N, Rivoirard J (2000) Indices of collocation between populations. In: Checkley DM, Hunter LR, Motos L, van der Lingen CD (eds) Report of a workshop on the use of the Continuous Underway Fish Egg Sampler (CUFES) for mapping spawning habitats of pelagic fish. Rep 14, GLOBEC International Project Office, Plymouth, p 48-52

Boudreau SA, Anderson SC, Worm B (2011) Top-down interactions and temperature control of snow crab abundance in the northwest Atlantic Ocean. Mar Ecol Prog Ser 429: 169-183

Bourdages H, Archambault D, Morin B, Fréchet A, Savard L, Grégoire F, Bérube M (2003) Preliminary results from the groundfish and shrimp multidisciplinary survey from August 2003 in the northern Gulf of St. Lawrence. Sci Advis Sec Res Doc 2003/078. Department of Fisheries and Oceans, Ottawa

Bourdages H, Archambault D, Morin B, Fréchet A, Savard L, Grégoire F, Dufour R (2004) Preliminary results from the groundfish and shrimp multidisciplinary survey from August 2004 in the northern Gulf of St. Lawrence. Sci Advis Sec Res Doc 2004/112. Department of Fisheries and Oceans, Ottawa

Bourdages H, Savard L, Archambault D, Valois S (2007) Results from the August 2004 and 2005 comparative fishing experiments in the northern Gulf of St. Lawrence between the CCGS Alfred Needler and the CCGS Teleost. Can Tech Rep Fish Aquat Sci 2750

Bourdages $\mathrm{H}$, Archambault D, Bernier B, Fréchet A and others (2010) Preliminary results from the groundfish and shrimp multidisciplinary survey in August 2009 in the northern Gulf of St. Lawrence. Can Tech Rep Fish Aquat Sci 1226

Brattey J, Cadigan NG, Dwyer K, Healey BP and others (2010) Assessment of the cod (Gadus morhua) stock in NAFO Divisions 2J+3KL in 2009. Sci Advis Sec Res Doc 2010/103. Department of Fisheries and Oceans, Ottawa

Bromley PJ (1994) The role of gastric evacuation experiments in quantifying the feeding rates of predatory fish. Rev Fish Biol Fish 4:36-66

Bundy A, Heymans JJ, Morisette L, Savenkoff C (2009) Seals, cod, and forage fish: a comparative exploration of variations in the theme of stock collapse and ecosystem change in four Northwest Atlantic ecosystems. Prog 
Oceanogr 81:188-206

Caddy JF, Wade E, Surette T, Hebert M, Moriyasu M (2005) Using an empirical traffic light procedure for monitoring and forecasting in the Gulf of St. Lawrence fishery for the snow crab, Chionoecetes opilio. Fish Res 76:123-145

Chabot D (2004) Chronic non-lethal levels of hypoxia limit distribution and growth of Atlantic cod (Gadus morhua) in the northern Gulf of St. Lawrence, Canada. In: Rupp GL, White MD (eds) Proc 7th Int Symp Fish Physiol Toxicol Water Qual, Tallinn, Estonia, May 12-15, 2003. EPA 600/R-04/049. U.S. Environmental Protection Agency, Ecosystems Research Division, Athens, GA, p 183-205

> Chabot D, Sainte-Marie B, Briand K, Hanson JM (2008) Atlantic cod and snow crab predator-prey size relationship in the Gulf of St. Lawrence, Canada. Mar Ecol Prog Ser 363:227-240

Choi JS, Frank KT, Leggett WC, Drinkwater K (2004) Transition to an alternate state in a continental shelf ecosystem. Can J Fish Aquat Sci 61:505-510

Colbourne EB, Anderson JT (2003) Biological response in a changing ocean environment in Newfoundland waters during the latter decades of the 1900s. ICES Mar Sci Symp 219:169-181

Colbourne E, Craig J, Fitzpatrick C, Senciall D, Stead P, Bailey W (2009) An assessment of the physical oceanographic environment on the Newfoundland and Labrador Shelf in NAFO Subareas 2 and 3 during 2009. NAFO SCR Doc 10/16, NAFO, Dartmouth, NS

Conan GY, Starr M, Comeau M, Therriault JC, Hernàndez FXM, Robichaud G (1996) Life history strategies, recruitment fluctuations, and management of the Bonne Bay Fjord Atlantic snow crab (Chionoecetes opilio). In: High latitude crabs: biology, management, and economics. Rep AK-SG-96-02. Alaska Sea Grant Program, Anchorage, AK, p 59-97

Couturier C (2003) Évacuation gastrique chez la morue franche Gadus morhua: influence de la résistance du tégument de la proie. MSc thesis. Université du Québec à Rimouski

Dawe EG, Parsons DG, Colbourne EB (2008) Relationships of sea ice extent and bottom water temperature with abundance of snow crab (Chionoecetes opilio) on the Newfoundland - Labrador Shelf. ICES CM Doc 2008/ B02. ICES, Copenhagen

Dawe E, Mullowney D, Stansbury D, Skanes K and others (2011) An assessment of Newfoundland and Labrador snow crab (Chionoecetes opilio) in 2009. Sci Advis Sec Res Doc 2011/073. Department of Fisheries and Oceans, Ottawa

DFO (Department of Fisheries and Oceans Canada) (2007) Final report of the Fisheries Oceanography Committee 2007 annual meeting; 3-5 April 2007. Sci Advis Sec Proc Ser 2007/053. Department of Fisheries and Oceans, Ottawa

DFO (2009) Proceedings of the National Workshop on the Impacts of Seals on Fish Populations in Eastern Canada (Part 2); 24-28 November 2008. Sci Advis Sec Proc Ser 2009/020. Department of Fisheries and Oceans, Ottawa

DFO (2010) Assessment of capelin in SA $2+$ Div. 3KL in 2010. Sci Advis Sec Sci Advis Rep 2010/090. Department of Fisheries and Oceans, Ottawa

DFO (2011a) Stock assessment of northern (2J3KL) cod in 2011. Sci Advis Sec Sci Advis Rep 2011/041. Department of Fisheries and Oceans, Ottawa

DFO (2011b) Assessment of the estuary and Gulf of St.
Lawrence (Divisions 4RST) capelin stock in 2010. Sci Advis Sec Sci Advis Rep 2011/008. Department of Fisheries and Oceans, Ottawa

DFO (2012) Assessment of shrimp stocks in the estuary and Gulf of St. Lawrence in 2011. Sci Advis Sec Sci Advis Rep 2012/006. Department of Fisheries and Oceans, Ottawa

> Dos Santos J, Jobling M (1992) A model to describe gastric evacuation in cod (Gadus morhua L.) fed natural prey. ICES J Mar Sci 49:145-154

> Dwyer KS, Buren A, Koen-Alonso M (2010) Greenland halibut diet in the Northwest Atlantic from 1978 to 2003 as an indicator of ecosystem change. J Sea Res 64:436-445

Frank KT, Petrie B, Choi JS, Leggett WC (2005) Trophic cascades in a formerly cod-dominated ecosystem. Science 308:1621-1623

Frank KT, Petrie B, Shackell NL, Choi JS (2006) Reconciling differences in trophic control in mid-latitude marine ecosystems. Ecol Lett 9:1096-1105

- Frank KT, Petrie B, Shackell NL (2007) The ups and downs of trophic control in continental shelf ecosystems. Trends Ecol Evol 22:236-242

Frank KT, Petrie B, Fisher JA, Leggett WC (2011) Transient dynamics of an altered large marine ecosystem. Nature 477:86-89

Fréchet A, Gauthier J, Schwab P, Lambert Y and others (2009) The status of cod in the Northern Gulf of St. Lawrence (3Pn, 4RS) in 2008. Sci Advis Sec Res Doc 090. Department of Fisheries and Oceans, Ottawa

Hanson JM, Chouinard GA (2002) Diet of Atlantic cod in the southern Gulf of St. Lawrence as an index of ecosystem change, 1959-2000. J Fish Biol 60:902-922

Healey BP (2011) Greenland halibut (Reinhardtius hippoglossoides) in NAFO Subarea 2 and Divisions 3KLMNO: stock trends based on annual Canadian research vessel survey results during 1978-2010. NAFO SCR Doc 11/31, Ser N5916, NAFO, Dartmouth, NS

Hutchings JA, Myers RA (1994) What can be learned from the collapse of a renewable resource? Atlantic cod, Gadus morhua, of Newfoundland and Labrador. Can J Fish Aquat Sci 51:2126-2146

ICES (International Council for the Exploration of the Sea) (2008) Report of the Working Group on Multispecies Assessment Methods (WGSAM), 6-10 October 2008, ICES Headquarters, Copenhagen. ICES CM 2008/RMC: 06. ICES, Copenhagen

Jobling M (1987) Influences of food particle size and dietary energy content on patterns of gastric evacuation in fish: test of physiological model of gastric emptying. J Fish Biol 30:299-314

Koeller P, Fuentes-Yaco C, Platt T, Sathyendranath S and others (2009) Basin-scale coherence in phenology of shrimps and phytoplankton in the North Atlantic Ocean. Science 324:791-793

Koen-Alonso M, Pepin P, Mowbray M (2010) Exploring the role of environmental and anthropogenic drivers in the trajectories of core fish species of the NewfoundlandLabrador marine community. NAFO SCR Doc 10/37, Ser N5795, NAFO, Dartmouth; NS

Lawson JW, Magalh es AM, Miller EH (1998) Important prey species of marine vertebrate predators in the northwest Atlantic: proximate composition and energy density. Mar Ecol Prog Ser 164:13-20

Lilly GR (1984) Predation by Atlantic cod on shrimp and crabs off northeastern Newfoundland in autumn of 1977 82. ICES C.M.1984/G:53. ICES, Copenhagen 
Lilly GR (1991) Interannual variability in predation by cod (Gadus morhua) on capelin (Mallotus villosus) and other prey off southern Labrador and northeastern Newfoundland. ICES Mar Sci Symp 193:133-146

Lilly GR (2008) The decline, recovery, and collapse of Atlantic cod (Gadus morhua) off Labrador and eastern Newfoundland. In: Kruse GH, Drinkwater K, Ianelli JN, Link JS, Stram DL, Wespestad V, Woodby D (eds) Resiliency of gadid stocks to fishing and climate change. Alaska Sea Grant, University of Alaska Fairbanks, Fairbanks, AK, p 67-88

Lilly GR, Parsons DG, Kulka DW (2000) Was the increase in shrimp biomass on the Northeast Newfoundland Shelf a consequence of a release in predation pressure from cod? J Northw Atl Fish Sci 27:45-61

Lilly GR, Wieland K, Rothschild BJ, Sundby S and others (2008) Decline and recovery of Atlantic cod (Gadus morhua) stocks throughout the North Atlantic. In: Kruse GH, Drinkwater K, Ianelli JN, Link JS, Stram DL, Wespestad V, Woodby D (eds) Resiliency of gadid stocks to fishing and climate change. Alaska Sea Grant, University of Alaska Fairbanks, Fairbanks, AK, p 39-66

Litzow MA, Ciannelli L (2007) Oscillating trophic control induces community reorganization in a marine ecosystem. Ecol Lett 10:1124-1134

Marcello LA, Mueter FJ, Dawe EG, Moriyasu M (2012) Effects of temperature and gadid predation on snow crab recruitment: comparisons between the Bering Sea and Atlantic Canada. Mar Ecol Prog Ser 469: 249-261

McCallum B, Walsh SJ (1996) Groundfish survey trawls used at the Northwest Atlantic Fisheries Centre, 1971present. Sci Counc Stud NAFO 29:93-103

McQuinn IH (2009) Pelagic fish outburst or suprabenthic habitat occupation: legacy of the Atlantic cod (Gadus morhua) collapse in eastern Canada. Can J Fish Aquat Sci 66:2256-2262

> Montevecchi WA, Piatt J (1984) Composition and energy contents of mature inshore spawning capelin (Mallotus villosus): implications for seabird predators. Comp Biochem Physiol A Physiol 78:15-20

Mueter FJ, Broms C, Drinkwater KF, Friedland KD and others (2009) Ecosystem responses to recent oceanographic variability in high-latitude Northern Hemisphere ecosystems. Prog Oceanogr 81:93-110

Orensanz JM, Ernst B, Armstrong DA, Stabeno P, Livingston $P$ (2004) Contraction of the geographic range of distribution of snow crab (Chionoecetes opilio) in the eastern Bering Sea - an environmental ratchet? Calif Coop Ocean Fish Invest Rep 45:65-79

Orr D, Veitch PJ, Sullivan DJ, Skanes K (2011) The status of the northern shrimp (Pandalus borealis) resource off Labrador and northeastern Newfoundland as of March 2010. Sci Advis Sec Res Doc 2011/004. Department of Fisheries and Oceans, Ottawa

> Ouellet P, Savard L, Larouche P (2007) Spring oceanographic conditions and northern shrimp Pandalus borealis recruitment success in the northwestern Gulf of St. Lawrence. Mar Ecol Prog Ser 339:229-241

Parsons DG (2005a) Predators of northern shrimp, Pandalus borealis (Pandalidae), throughout the North Atlantic. Mar Biol Res 1:48-58

Parsons DG (2005b) Interactions between northern shrimp, Pandalus borealis (Pandalidae), and its key predators within the eastern Newfoundland and Labrador marine ecosystem. Mar Biol Res 1:59-67

Perez MA (1994) Calorimetry measurements of energy value of some Alaskan fishes and squids. Tech Memo NMFS-AFSC-32. U.S. Department of Commerce, NOAA, NMFS, Seattle, WA

Petrie B, Frank KT, Shackell NL, Leggett WC (2009) Structure and stability in exploited marine fish communities: quantifying critical transitions. Fish Oceanogr 18:83-101

$>$ Rose GA, O'Driscoll RL (2002) Capelin are good for cod: Can the northern stock rebuild without them? ICES J Mar Sci 59:1018-1026

Sainte-Marie B, Lafrance M (2002) Growth and survival of recently settled snow crab Chionoecetes opilio in relation to intra- and intercohort competition and cannibalism: a laboratory study. Mar Ecol Prog Ser 244:191-203

Sainte-Marie B, Sévigny JM, Smith BD, Lovrich GA (1996) Recruitment variability in snow crab (Chionoecetes opilio): pattern, possible causes, and implications for fishery management. In: High latitude crabs: biology, management, and economics. Rep AK-SG-96-02. Alaska Sea Grant Program, Anchorage, AK, p 451-478

Savard L, Bourdages H (2010) Estimation of northern shrimp Pandalus borealis biomass and abundance from the annual trawl survey in the estuary and the northern Gulf of St. Lawrence between 1990 and 2009. Sci Advis Sec Res Doc 2010/061. Department of Fisheries and Oceans, Ottawa

Savenkoff C, Savard L, Morin B, Chabot D (2006) Main prey and predators of northern shrimp (Pandalus borealis) in the northern Gulf of St. Lawrence during the mid-1980s, mid-1990s, and early 2000s. Can Tech Rep Fish Aquat Sci 2639

Shackell NL, Frank KT, Fisher JA, Petrie B, Leggett WC (2010) Decline in top predator body size and changing climate alter trophic structure in an oceanic ecosystem. Proc R Soc Lond B Biol Sci 277:1353-1360

Swain DP, Mohn RK (2012) Forage fish and factors governing recovery of Atlantic cod (Gadus morhua) on the eastern Scotian Shelf. Can J Fish Aquat Sci 69:997-1001

Walsh SJ, McCallum BR (1996) Performance of the Campelen 1800 shrimp trawl during the 1995 Northwest Atlantic Fisheries Centre autumn groundfish survey. Sci Counc Stud NAFO 29:105-116

Warren WG (1996) Report on the comparative fishing trial between the 'Gadus Atlantica' and 'Teleost'. NAFO SCR Doc 96/28, Ser No N2701, NAFO, Dartmouth, NS

Warren W, Brodie W, Stansbury D, Walsh S, Morgan J, Orr D (1997) Analysis of the 1996 comparative fishing trial between the 'Alfred Needler' with the Engel 145' Trawl and the 'Wilfred Templeman' with the Campelen 1800 Trawl. NAFO SCR Doc 97/68, Ser No N2902, NAFO, Dartmouth, NS

Wieland K, Siegstad H (2012) Environmental factors affecting recruitment of northern shrimp Pandalus borealis in West Greenland waters. Mar Ecol Prog Ser 469:297-306

Wieland K, Storr-Paulsen M, Sünksen K (2007) Response in stock size and recruitment of northern shrimp (Pandalus borealis) to changes in predator biomass and distribution in West Greenland waters. J Northwest Atl Fish Sci 39: 21-33

Worm B, Myers RA (2003) Meta-analysis of cod-shrimp interactions reveals top-down control in oceanic food webs. Ecology 84:162-173 